Dénes Kálmán ${ }^{1}$ - Kovács Zoltán²

\title{
A klímaváltozás hatásai a vízgazdálkodásra
}

\section{Effects of Climate Change on Water Management}

A globalizáció okozta klímaváltozásnak számos káros, napjainkban egyre gyakrabban jelentkező hatása és következménye figyelhetö meg. Ennek következtében világszerte megfigyelhető gondok és problémák alakultak ki az öntözési nehézségektöl kezdve, a különbözö betegségek megjelenésén át, egészen háborúk kitöréséig bezárólag. Tehát jó okkal gondolunk erre mint problémára. A szerzők dolgozatukban azokat a lehetöségeket és müszaki feladatokat mutatják be, amelyeket a klímaváltozás káros következményeinek felszámolása, illetve csökkentése érdekében lehet végrehajtani.

Kulcsszavak: klímaváltozás, aszály, árvíz, vízkészlet, víztakarékosság

Climate change caused by globalisation has a number of harmful effects and consequences that are more and more common today. As a result, worldwide problems have emerged, ranging from irrigation difficulties to the emergence of various diseases, up to the outbreak of wars. So we think of this as a problem with good reason. The authors present in their study the possibilities and technical tasks that can be carried out in order to eliminate and reduce the harmful consequences of climate change.

Keywords: climate change, drought, flood, water resources, water saving

\section{Bevezetés}

A meggyfákon új, életerős hajtások jelentek meg egészséges levelekkel. 1-2 héttel később kinyíltak a virágok, majd a méhek áldozatos munkája nyomán a termés megkötött. A történet

Nemzeti Közszolgálati Egyetem, egyetemi docens, e-mail: denes.kalman@uni-nke.hu, ORCID: https://orcid org/0000-0002-2951-7172

2 Nemzeti Közszolgálati Egyetem, egyetemi docens, e-mail: kovacs.zoltan@uni-nke.hu, ORCID: https://orcid. org/0000-0001-9098-1997 
egyetlen negatívuma, hogy mindez 2018. október végén történt a Pest megyei Tahitótfaluban. A klímaváltozás elkezdődött, a hatásait pedig a bőrünkön érezzük.

Kár lenne tagadni, hogy a klímaváltozás folyamatának vannak pozitív hatásai is. A felmelegedés miatt például télen egyre magasabb a napi átlaghőmérséklet, ${ }^{3}$ igy jelentősen kevesebb energiát kell fütésre felhasználnunk. Ezzel egyidejüleg kevesebb hó esik, így nem kell a hó eltakarítására annyi időt, pénzt és energiát fordítani, mint 30-40 évvel ezelőtt, vagy például 1986-87 telén. ${ }^{4}$ Megfigyelhető továbbá, hogy a magasabb téli átlaghőmérséklet miatt hazánk élővizein nem alakul ki tartósan vastag jégréteg, így az év egyre nagyobb részében fenntartható a vízi közlekedés és szállítás. A kevesebb hó miatt kevésbé csúszósak a közlekedési utak, így kisebb a közlekedési balesetek száma. ${ }^{5}$ Felelőtlenség lenne ugyan azt kijelenteni, hogy ez utóbbi kizárólagosan az enyhébb tél miatt van, de az biztosan állítható, hogy száraz úton lényegesen jobb a közlekedésbiztonság.

A klímaváltozás negatív hatásairól szükségszerüen sokkal többet lehet hallani a különböző médiumokban, mivel a folyamat és annak következményei nagyon sok problémát és kellemetlenséget okoznak a társadalomnak. Az elmúlt években számos publikáció is megjelent, amelyek ennek a folyamatnak a különböző okait, hatásait és következményeit vizsgálták és mutatták be a lakosságra és a Magyar Honvédségre vonatkoztatva, egyúttal - ezekkel összefüggésben - a biztonságra ${ }^{6}$ és a természeti környezetre. „Az extrém időjárás hatással van a katonai feladatokra is. 2018-ban például jelentősen megnőtt a Dunához köthető robbanótestek bejelentésének száma, ami föleg a rendkívül alacsony vízállásnak volt köszönhetö."7

A klímaváltozást évtizedekkel ezelőtt prognosztizálták, annak lehetséges hatásait és problémáinak megoldási lehetőségeit pedig hosszú évek óta vizsgálják és kutatják. Stratégiai tervek (például a 2008-2025 közötti időszakra vonatkozó Nemzeti Éghajlatváltozási Stratégia), készültek, azonban mégsem történt semmilyen látványos előrelépés nemcsak a folyamat megállításra, de még a lassítására sem. Vajon mi lehet ennek az oka? Miért nem érti meg az ember, hogy a megtermelt energiával takarékoskodni kell? Miért nem gyűjti szelektíven a háztartásában keletkező hulladékot, hogy csökkenteni tudja a környezet felesleges terhelését? Miért nincs nagyobb kormányzati-politikai szándék és ráhatás (törvények és jogszabályok, adókedvezmények, támogatások által) a környezettudatos életre? Miért fontosabb a profit a gazdasági nagyhatalmak, gazdasági társaságok és nagytőkések számára, mint az, hogy egy élhető bolygót adjanak át gyermekeiknek, amikor már napjainkra is több emberöltőre való pénzt halmoztak fel? Cikkünkben azonban nem ezekre a kérdésekre keressük a választ. Műszaki emberekként sokkal inkább a jelenlegi problémákra keressük a megoldásokat.

\footnotetext{
Országos Meteorológiai Szolgálat: Magyarország.

Kurunczi Rita: A '86-'87-es tél. Időkép, 2010.

KSH Közlekedési balesetek (1990-). Központi Statisztikai Hivatal.

Bővebben lásd: Padányi József: Éghajlatváltozás és a biztonság összefüggései. Hadtudomány, 19. (2009), 1-2. 33-46.

Ember István: A dunai alacsony vízállások tüzszerész tapasztalatai 2018-ban. Müszaki Katonai Közlöny, 29. (2019), 3. $65-77$.

8 A teljes dokumentum megtalálható: 29/2008. (III. 20.) OGY határozat a Nemzeti Éghajlatváltozási Stratégiáról.
} 
A klímaváltozás okait, hatásait és káros következményeit annak érdekében vizsgáljuk, hogy egyszerü és megvalósítható megoldást kínáljunk az olvasónak a kialakult problémák megszüntetésére vagy enyhítésére, valamint a jövőben várható káros hatások megelőzésére.

\section{Az éghajlatváltozás okai}

A klímaváltozás okait vizsgálva könnyen juthatunk arra az elhamarkodott következtetésre, hogy az emberi tevékenység az egyetlen és egyedüli oka a légkör fokozódó felmelegedésének. Az éghajlatváltozásnak a valóságban azonban három számottevő oka van:

- Az éghajlati rendszer belső ingadozásai;

- Természetes külső tényezők;

- naptevékenység;

- a napállandó fluktuációjának idősora;

- vulkánkitörések.

- Antropogén hatások;

- az üvegházhatás erösödése;

- aeroszolok;

- a földi növényzet szerkezetének megváltozása;

- az antropogén hötermelés lokális következményei. ${ }^{9}$

Az antropogén hatások változásáért felelős emberi tevékenység hosszú évtizedek óta egyre nagyobb hatást gyakorol az éghajlatra és bolygónk átlaghőmérsékletére. A növekvő népesség egyre növekvő igényeinek kiszolgálását biztosító ipari és mezőgazdasági termelés lényegesen növeli a légkörben lévő üvegházhatású gázok koncentrációját, ami jelentős mértékben tovább fokozza az üvegházhatást, és ezáltal gyorsítja a globális felmelegedést. Összességében tehát mégis megállapítható, hogy az éghajlatváltozás felgyorsulása számos emberi tevékenység közös eredménye.

\section{Az éghajlatváltozás hatásai}

A klímaváltozás az emberiségre és a természetre egyaránt súlyos és fenyegető következményekkel járhat. A változás régen elkezdődött, ezért annak megelőzésére már nincs lehetőségünk, hiába ez lett volna a legegyszerübb és legolcsóbb megoldás.

A klíma változásához éppen ezért elsősorban alkalmazkodnunk kell, ami azt jelenti, hogy kisebb-nagyobb mértékben át kell alakítanunk az életünket. Ezt követően a változás mérséklésére kell törekednünk, végül minél előbb, azaz minél alacsonyabb átlaghőmérsékleten meg kell állítanunk bolygónk melegedését.

9 Országos Meteorológiai Szolgálat: Éghajlatváltozás okai. 
A 2017-2030 közötti időszakra vonatkozó második Nemzeti Éghajlatváltozási Stratégia10 (NÉS-2) kidolgozása során a közpolitikai cél egy olyan cselekvési terv volt, amely lefekteti azokat a célkitüzéseket, amelyek megvalósításával az éghajlatváltozás által előidézett hatások hosszú távon kezelhetők. Ez két úton valósítható meg. A nemzetközi erőfeszítésekkel összhangban mérsékelnünk kell az üvegházhatású gázok kibocsátását, továbbá - hazánk érdekeit szem előtt tartva - növelnünk kell a szén-dioxid-elnyelő kapacitásainkat.

A NÉS-2 magában foglalja:

- az éghajlatváltozás várható magyarországi hatásainak természeti és társadalmi-gazdasági következményeinek, valamint az ökoszisztémák és az ágazatok éghajlati sérülékenységének értékelését;

- az üvegházhatású gázok kibocsátásának 2050-ig tartó csökkentésére vonatkozó célokat, prioritásokat és cselekvési irányokat tartalmazó Hazai Dekarbonizációs Útitervet;

- a Nemzeti Alkalmazkodási Stratégiát, amelynek fő célja az éghajlatváltozással és a klímabiztonsággal összefüggő kockázatok megelőzése és a károk mérséklése;

- az éghajlatváltozás megelőzését, valamint az éghajlatváltozásra való felkészülést és alkalmazkodást szolgáló szemléletformálási tevékenységek célrendszerét. ${ }^{11}$

Az éghajlatváltozás egyike azoknak a kihívásoknak, amelyek közvetlenül befolyásolják az emberek mindennapi életét és életminőségét, továbbá veszélyeztetik a természeti erőforrásokat és károsítják az épített környezetet és infrastruktúrát. Emiatt hazánkban a folyamat várható hatásai a természeti erőforrásokra kiemelt figyelmet kell hogy kapjanak. Ezek között részletesen kell vizsgálni a vizeket, a talajt, az erdőket és a biológiai sokféleséget.

Az éghajlatváltozás várható humán és társadalmi-gazdasági következményeit a NÉS-2 részletesen bemutatja. A vizsgált szakterületeken (például mezőgazdaság, katasztrófavédelem, épített környezet, települési infrastruktúra, energiagazdálkodás stb.) bekövetkező hatások önmagukban is komoly kihívást jelenthetnek az emberiségnek, ezek együttes hatása azonban megoldhatatlan feladat elé állíthatja a döntéshozókat és a szakembereket egyaránt. „A mezőgazdasági vízigényt tekintve pl. elmondható, hogy az ország egyes részein a növénytermesztés szinte állandó vízhiánnyal küszködik és öntözőcsatornák, illetve a felszín alatti vízkészletek igénybevételével öntözésre kényszerül. Ez alapvetően beruházás-igényes és nagyban emeli a termelési költségeket még akkor is, ha a termelékenységre és a termés minőségére egyaránt pozitív hatást gyakorol."12

Az elmúlt évtizedek kutatásai, publikációi és megfigyelései alapján arra a következtetésre jutottunk, hogy a problémák számottevő részét a csapadékvizek okozzák. Problémát okoz a sok csapadék, mert árvizet, villámárvizet okoz, és problémát okoz akkor is, ha kevés, mert a kialakuló aszály miatt például csökken a mezőgazdasági termelés. Ebből adódóan a csapadékok terület-

10 23/2018. (X. 31.) OGY határozat a 2018-2030 közötti időszakra vonatkozó, 2050-ig tartó időszakra is kitekintést nyújtó második Nemzeti Éghajlatváltozási Stratégiáról.

11 23/2018. (X. 31.) OGY határozat.

12 Berek Tamás: A víz, mint környezeti erőforrás a Kárpát-medencében, vízbázisok, vízbiztonság. In Csengeri János - Krajnc Zoltán (szerk.): A hadtudomány és a hadviselés komplexitása a XXI. században. Budapest, Nemzeti Közszolgálati Egyetem, 2015. 61-73. 
egységre vonatkozó mennyiségi változását mérni szükséges, ennek a változásnak a lehetséges következményeit pedig vizsgálni kell.

Magyarországon az átlagos havi csapadékösszegek értéke $\sim 30-70 \mathrm{~mm}^{13}$ között változik. Ebből adódóan hazánk éghajlati viszonyai között az egyes időegységek alatt leesett alábbi csapadékok már kivételesen nagynak számítanak:

- 1 perc alatt: $2 \mathrm{~mm}$;

- 1 óra alatt: $40 \mathrm{~mm}$;

- 1 nap alatt: $100 \mathrm{~mm}$;

- 1 év alatt: $1000 \mathrm{~mm}$.

Mindezek ismeretében tekintsünk át néhány esetet, amelyek az átlagosnál nagyobb esőzéssel jártak. Az 1. ábra a legmagasabb órás csapadékösszegeket mutatja Budapest belterület állomáson 1998-2017 között. Ezek közül érdemes kiemelni az alábbi két esetet:

2015. augusztus 17-én 83,3 mm hullott egy óra alatt Budapest belvárosában (az OMSZ14 székház területe).

2017. május 23-án intenzív csapadékrendszer özönvízszerü esőzést okozott Budapest több pontján. Egy óra alatt mintegy 44 mm csapadék hullott Budapest belvárosában (az OMSZ székház területe). ${ }^{15}$

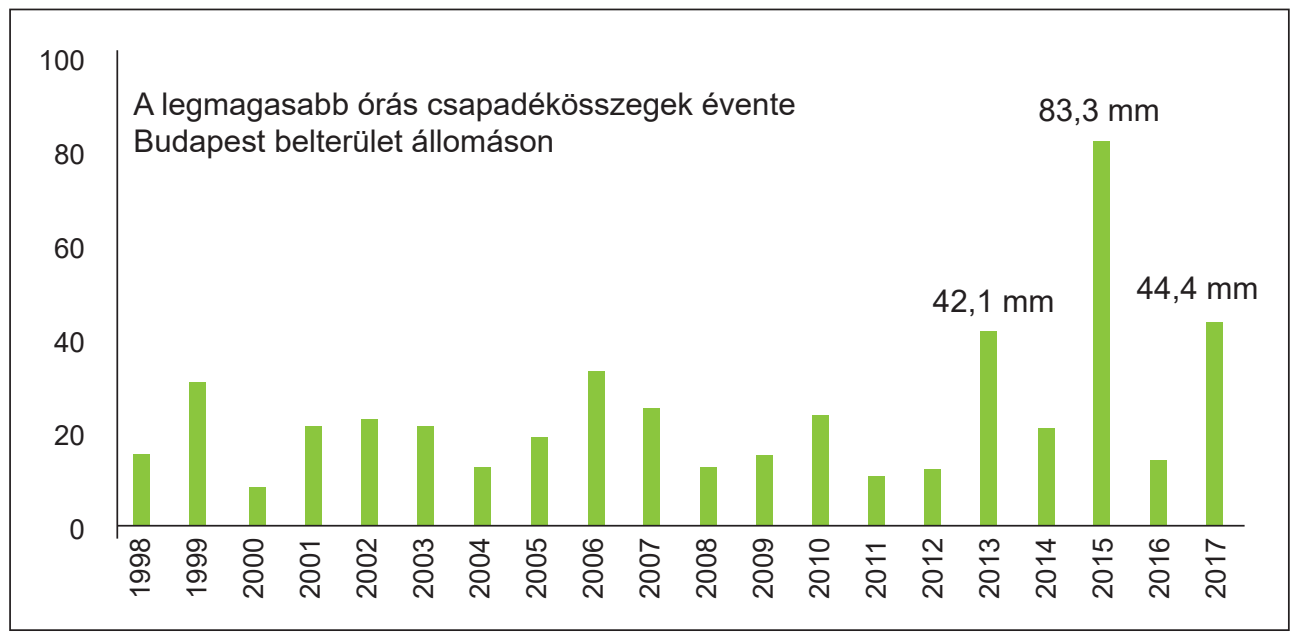

1. ábra. Az órás csapadékösszegek éves maximumai Budapest belterület állomáson

Forrás: Lakatos-Hoffmann (2017) i. m.

13 Országos Meteorológiai Szolgálat: Magyarország csapadék viszonyai.

14 OMSZ: Az Országos Meteorológiai Szolgálat nevének rövidítése.

15 Lakatos Mónika - Hoffmann Lilla: Rendkívüli csapadékhullás Budapest belvárosában. Országos Meteorológiai Szolgálat, 2017. 
Az OMSZ mérései alátámasztják, ${ }^{16}$ hogy a szélsőséges éghajlati események gyakoribbá váltak. Ez a ténymegállapítás, vagyis a legutóbbi évek heves időjárási eseményei indokolttá tehetik a mérnöki gyakorlatban használatos szabványok és a mértékadó csapadékmennyiségek felülvizsgálatát.

Az éghajlati változékonyság következtében a mérsékelt égövi területeken várhatóan kialakuló szélsőséges eseményeket és az általuk előidézett hatásokat foglalja össze az 1. táblázat.

1. táblázat. Éghajlati változékonyság, szélsőséges események és az általuk előidézett hatások a kontinenseinek mérsékelt égövi területére szorítkozva

\begin{tabular}{|c|c|}
\hline $\begin{array}{l}\text { A 21. század szélsöséges éghajlati jelenségeinek } \\
\text { elörelátható változásai és ezek valószínüsége } \\
\text { a kontinensek mérsékelt övi részeiben }\end{array}$ & $\begin{array}{c}\text { Az elörejelzett hatások példái (az egyes területeken az elöfordulás } \\
\text { megbizhatósága mindig magas) }\end{array}$ \\
\hline $\begin{array}{l}\text { A szárazföldön szinte mindenhol magasabb maxi- } \\
\text { mumhőmérsékletek, több meleg nap és höhullám. } \\
\text { (nagyon valószínü) }\end{array}$ & $\begin{array}{l}\text { - Az állat- és vadállomány növekvő hőterhelése. } \\
\text { - Turisztikai célterületek átalakulása. } \\
\text { - Megnő számos termény károsodásának kockázata. } \\
\text { - Növekvő kereslet az elektromos hütésre, csökken az energiaszolgál- } \\
\text { tatás megbizhatósága. }\end{array}$ \\
\hline $\begin{array}{l}\text { A szárazföldön magasabb minimumhőmérséklet, } \\
\text { kevesebb hideg és fagyos nap, ill. lehülési hullám. } \\
\text { (nagyon valószínü) }\end{array}$ & $\begin{array}{l}\text { - Csökken a hideg jelentősége a morbiditás és mortalitás jellemzőiben. } \\
\text { - Számos termény károsodásának kockázata csökken, miközben } \\
\text { - } \text { másoké nő. } \\
\text { - Egyes kártevők és betegséghordozók aktivitása nö, hatóköre tágul. } \\
\end{array}$ \\
\hline $\begin{array}{l}\text { Több intenzív csapadékkal járó esemény. } \\
\text { (nagyon valószínü, sok területen) }\end{array}$ & $\begin{array}{l}\text { - Az árvíz, földcsuszamlás, lavina és sárfolyam okozta káresemények } \\
\text { növekedése. } \\
\text { - Növekvő talajerózió. } \\
\text { - Az áradások növekvő vízhozama újra feltöltheti egyes ártéri területek } \\
\text { víztartó rétegeit. }\end{array}$ \\
\hline $\begin{array}{l}\text { Növekvő nyári szárazság a mérsékelt szélességeken } \\
\text { az aszálykockázat növekedése mellett. } \\
\text { (valószinü) }\end{array}$ & $\begin{array}{l}\text { - Csökkenő terméshozam. } \\
\text { - Az épületek alapozásának károsodása talajzsugorodás miatt. } \\
\text { - Csökkenő mennyiségü és minőségü vízellátás. } \\
\text { - Erdőtüzek kockázatának növekedése. }\end{array}$ \\
\hline
\end{tabular}

Forrás: Országos Meteorológiai Szolgálat: Hatások, alkalmazkodás.

A klímaváltozás hatására hazánkban az alábbi hatások bekövetkezése várható:

- az égövre jellemző vegetáció határainak eltolódása;

- a társulások és táplálékhálózatok átrendeződése;

- a természetes élővilág fajainak visszaszorulása, különösen az elszigetelt élőhelyeken;

- hosszú távon a biológiai sokféleség csökkenése;

- inváziós fajok terjedése, új inváziós fajok (például kártevő rovarok és gyomok) megjelenése;

- az élőhelyek szárazabbá válása (például vizes élőhelyek eltünése, homokterületek sivatagosodása);

- ökoszisztéma-funkciók károsodása;

- a talajok kiszáradása, a talajban lezajló biológiai folyamatok sérülése;

- a tüzesetek gyakoribbá válása. ${ }^{17}$

16 Lakatos-Hoffmann (2017) i. m.

17 Országos Meteorológiai Szolgálat: Hatások, alkalmazkodás. i. m. 


\section{Az éghajlatváltozásra adott válaszok}

Tekintettel arra, hogy a NÉS-2 prognózisa szerint Európa egyik legsérülékenyebb országa Magyarország, ezért a várható következmények elhárítása érdekében az alkalmazkodás és a felkészülés teendői be kell hogy épüljenek a szakpolitikai tervezésbe és a gazdasági döntéshozatalba. A fokozott kockázat miatt kiemelten kezelt területek: a) mezőgazdasági termésbiztonság; természeti értékeink; emberi egészség; vízgazdálkodás.

A NÉS-2-ben megfogalmazott Nemzeti Vízstratégia (Kvassay Jenő Terv, KJT) bemutatja a klímaváltozás negatív hatásait a vizeinkre és a hazai vízgazdálkodásra. A jövőbeni időjárási szélsőségek az elérhető víz mennyiségének csökkenését eredményezhetik, miközben a társadalom és gazdaság részéről a vízigények várhatóan növekedni fognak. A területi vízgazdálkodás (árvízmentesítés és -védekezés, síkvidéki vízrendezés, belvízvédekezés, mezőgazdasági vízgazdálkodás, folyógazdálkodás, vízi utak, vízenergia-hasznosítás) kulcsfontosságú. A KJT átfogó, hosszú távú céljai között kiemeli, hogy a vizek okozta károk megelőzését előtérbe kell helyezni a védekezés helyett; a vízgazdálkodási rendszerek és a területhasználati módok összehangolt alakításában pedig lényeges, hogy a víz káros bősége a vízhiány mérséklésére legyen fordítható. ${ }^{18}$

A KJT a célokon túl az azok eléréséhez szükséges intézkedéseket, súlyponti feladatokat is meghatározza, Ezek között jelennek meg:

- a vízvisszatartás és vízszétosztás a vizeink jobb hasznosítása érdekében;

- a kockázatmegelőző vízkárelhárítás; a vizek állapotának fokozatos javítása, a jó állapot elérése;

- a minőségi víziközmü-szolgáltatás és csapadékvíz-gazdálkodás;

- a társadalom és a víz viszonyának a javítása;

- a vízgazdálkodás gazdasági szabályozó rendszerének újjászervezése;

- a tervezés és irányítás megújítása. ${ }^{19}$

A Nemzeti Vízstratégiában megfogalmazott feladatokat, vagyis a hazai vízgazdálkodást, annak problémáit és az abban rejlő lehetőségeket évtizedek óta kutatjuk. A megállíthatatlannak látszó urbanizációs folyamatok miatt olyan következményekre (például növekvő vízigények miatt kialakuló vízhiány, fokozódó szennyvízterhelés stb.) kell felkészülnünk a vízgazdálkodásban (sok más terület mellett), amelyek kezelése a hagyományostól eltérő felkészültséget, módszereket és szemléletet igényelnek.

A településeken, elsősorban a városokban élő lakosság növekvő, koncentráltan jelentkező vízigényei, a kibocsátott szennyvíz minősége és mennyisége, a vízgyüjtő terület gyors válasza a csapadékra (például villámárvizek kialakulása), a felszíni lefolyás szennyezettségének speciális jellege és mértéke, továbbá a vízi és más közművek nagy koncentráltsága mind-mind különleges körülményeket jelentenek, amelyeket a települések vízgazdálkodásával foglalkozó műszaki szakembereknek figyelembe kell venniük. A települési vízgazdálkodás összetettségét

23/2018. (X. 31.) OGY határozat.

19 23/2018. (X. 31.) OGY határozat. 
az adja, hogy nem csupán a vízellátás és csatornázás infrastruktúrájával kell foglalkozni, hanem a környezetszennyezés egyidejü csökkentésével, a rendelkezésre álló vízkészletek fenntartható használatával, az árvízvédelemmel és a különböző ágazatok koordinálásával is.

Kiemelten fontos például a csatornázatlan területek szennyvízkezelésének megoldása. „Kis lélekszámú agglomerációk esetében vagy ott, ahol nem gazdaságos a központi szennyvíztisztító rendszerhez csatlakozni decentralizált, egyedi szennyvíztisztítási módok jöhetnek számításba. Egyedi kisberendezés alkalmazható családi házak, társas házak, üdülő területek, közintézmények, esetlegesen autópálya pihenők esetében, ahol a kapacitás nem haladja meg az 50-100 lakosegyenértéket." 20

\section{Az éghajlatváltozás vízgazdálkodásra ható káros következményei megszüntetésének vagy csökkentésének müszaki lehetöségei}

Tekintettel arra, hogy a problémák számottevő részét - közvetlenül vagy közvetve - a csapadékvizek okozzák, ezért célszerűnek tartjuk a megoldást is a "csapadékvizekben”, még inkább a természetes vizekkel való gazdálkodásban keresni.

Az OMSZ és a NÉS előrejelzései szerint a jövőben egyre gyakoribbá válik majd a több intenzív csapadékkal járó időjárási események száma. Ez a gyakorlatban azt jelenti, hogy néhány nap alatt esik le a teljes havi csapadékmennyiség. Ebből adódóan nem engedhetjük meg, hogy ez a vízmennyiség felhasználás nélkül, rövid időn és úton belül vízelvezető árokban folyjon le a területről.

A legnagyobb tározó térfogat a talaj, azonfelül ingyen és nagy mennyiségben rendelkezésre áll. A lakott településeken kívüli terepről lefolyó csapadékvizeknek ráadásul megvan az a nagy előnye, hogy nem tartalmazza a városokban nagy mennyiségben megtalálható, élő szervezetekre rendkívül káros szennyezőanyagokat, mint a nehézfémeket, olajokat stb. Annak érdekében tehát, hogy a területre hulló csapadékvíz nagyobb hányada helyben hasznosítható legyen, elő kell segíteni a csapadék talajba történő beszivárgását. Ezáltal egyrészt megnöveljük a talajban elraktározott (és onnan később felhasználható) vízkészlet mennyiségét, másrészt a nagy intenzitású csapadékok nem okoznak majd komoly pusztítással járó villámárvizeket, ezáltal károkat.

A következő néhány műszaki megoldás egyszerü és könnyen kivitelezhető, ugyanakkor nagyon is fontos válaszlépés lehet az éghajlatváltozás következtében kialakult és a jövőben várhatóan fokozódó vízhiányra:

- csapadékvíz-visszatartás a vízgyüjtő terület domborzati, növényborítottsági és talajadottsági tulajdonságainak módosításával;

- csapadékvíz-visszatartás tározók építésével;

- csapadékvíz-visszatartás szikkasztóárkok vagy szikkasztóakna létesítésével;

- csapadékvízgyűjtés ingatlanok területén;

- föld alatti vízkészletek (rétegvizek) visszatöltése;

20 Karches Tamás - Papp Tamás: Egyedi szennyvíztisztító kisberendezés alkalmazhatóságának bemutatása. Müszaki Katonai Közlöny, 28. (2018), 4. 158-163. 
- vésztározók, árapasztó tározók építése;

- vízfolyások vízszintjének emelése fix és mozgatható fenékküszöb építésével;

- vízfolyások mederrendezése (meder kotrása, hordalékfogók építése stb.);

- mesterséges csatornák építése öntözés miatt, valamint árapasztás-árvízmegosztás érdekében.

\section{6. Összegzés}

Hazánk rövid távon néhány gazdasági szempont alapján ugyan nyertese lehet a klímaváltozásnak, hosszú távon azonban várhatóan szembe kell néznünk számos súlyos, az életmódunkat is befolyásoló változással. Az egyre súlyosbodó klímaválság megoldásának a legegyszerűbb módja az lenne, ha egyik napról a másikra leállnánk a fosszilis energiahordozók elégetésével, és teljesen áttérnénk a megújuló energiák felhasználására. Ezt kivitelezni azonban a jelenkori társadalom igényei, a politikai és föként a gazdasági érdekek miatt meggyőződésem szerint lehetetlen. A klímaváltozásra, annak káros hatásaira azonban megoldást kell adnunk.

A jövőben egyre fokozódó vagy elöre láthatóan bekövetkező különféle problémák kezelése komplex megoldást igényel. Ebben a munkában a műszaki szakemberek javaslatokat és müszaki megoldásokat fogalmaznak meg, a döntéseket pedig ezek alapján a politikusok hozzák meg, majd megalkotják a végrehajtáshoz szükséges jogszabályokat.

\section{Felhasznált irodalom}

Berek Tamás: A víz, mint környezeti erőforrás a Kárpát-medencében, vízbázisok, vízbiztonság. In Csengeri János - Krajnc Zoltán (szerk.): A hadtudomány és a hadviselés komplexitása a XXI. században. Budapest, Nemzeti Közszolgálati Egyetem, 2015. 61-73. Online: http://real.mtak.hu/31932/7/ konyv_vegleges_mta_real.pdf

Ember István: A dunai alacsony vízállások tűzszerész tapasztalatai 2018-ban. Müszaki Katonai Közlöny, 29. (2019), 3. 65-77. Online: https://doi.org/10.32562/mkk.2019.3.5

Karches Tamás - Papp Tamás: Egyedi szennyvíztisztító kisberendezés alkalmazhatóságának bemutatása. Müszaki Katonai Közlöny, 28. (2018), 4. 158-163. Online: https://folyoirat.ludovika.hu/index.php/ mkk/article/view/1536/853

Padányi József: Éghajlatváltozás és a biztonság összefüggései. Hadtudomány, 19. (2009), 1-2. 33-46. Online: http://mhtt.eu/hadtudomany/2009/1_2/033-046.pdf

\section{Jogi források}

29/2008. (III. 20.) OGY határozat a Nemzeti Éghajlatváltozási Stratégiáról. Online: https://mkogy. jogtar.hu/jogszabaly?docid=a08h0029.OGY

23/2018. (X. 31.) OGY határozat a 2018-2030 közötti időszakra vonatkozó, 2050-ig tartó időszakra is kitekintést nyújtó második Nemzeti Éghajlatváltozási Stratégiáról. Online: www.parlament.hu/ irom40/15783/15783.pdf 


\section{Internetes források}

KSH Közlekedési balesetek (1990-). Központi Statisztikai Hivatal. Online: www.ksh.hu/docs/hun/xstadat/ xstadat_eves/i_ods001.html

Kurunczi Rita: A '86-'87-es tél. Idökép, 2010. Online: www.idokep.hu/hirek/a-86-87-es-tel-

Lakatos Mónika - Hoffmann Lilla: Rendkivüli csapadékhullás Budapest belvárosában. Országos Meteorológiai Szolgálat, 2017. Online: www.met.hu/ismeret-tar/erdekessegek_tanulmanyok/index. php?id=1885\&hir=Rendkivuli_csapadekhullas_Budapest_belvarosaban

Országos Meteorológiai Szolgálat: Éghajlatváltozás okai. Online: www.met.hu/eghajlat/eghajlatvaltozas/ eghajlatvaltozas_okai/

Országos Meteorológiai Szolgálat: Hatások, alkalmazkodás. Online: www.met.hu/eghajlat/eghajlatvaltozas/hatasok-alkalmazkodas/

Országos Meteorológiai Szolgálat: Magyarország. Online: www.met.hu/eghajlat/eghajlatvaltozas/ megfigyelt_valtozasok/Magyarorszag/

Országos Meteorológiai Szolgálat: Magyarország csapadék viszonyai. Online: www.met.hu/eghajlat/ magyarorszag_eghajlata/altalanos_eghajlati_jellemzes/csapadek/ 